\title{
Clinicopathologic And Prognostic Features In Gallbladder Malignancies: Retrospective Analysis Of Five Thousand Two Hundred Six Cases
}

\author{
Safra Kesesi Malignitelerinde Klinikopatolojik ve Prognostik Özellikler: Beş Bin iki \\ Yüz Altı Olgunun Retrospektif Olarak Incelenmesi
}

\author{
(D) Murat Ferhat Ferhatoğlu, (D) Kazım Şenol*, (D) Taner Kıvılcım, (D) Abdulcabbar Kartal, (D) Alp Gürkan \\ Okan University Faculty of Medicine, Department of General Surgery, Istanbul, Turkey \\ ${ }^{*}$ Koç University Faculty of Medicine, Department of General Surgery, Istanbul, Turkey
}

\section{Abstract}

Aim: Gallbladder cancer is the sixth most common cancer of gastrointestinal system. Clinical presentation may not be distinguished from cholelithiasis or cholecystitis and most patients are diagnosed intraoperatively or in the postoperative histologic examination. In this study, we aimed to investigate the association of incidentally detected gallbladder cancer with gallbladder premalignant lesions, age, gender, ultrasonography features and gallbladder stones.

Methods: Demographic, clinical characteristics and pathology results of 5206 patients undergoing cholecystectomy between January 2012 and December 2015 were evaluated retrospectively.

Results: Of the 3884 (74.6\%) patients were female. Pathologic reports showed premalignant and malignant lesions in 102 (1.95\%) cases. Metaplasia was significantly more common in females, while no significant difference was found between development of dysplasia and cancer according to gender. Gallbladder stone was found as a risk factor in the development of metaplasia. Gallbladder wall thickening and advanced age are most important risk factors of gallbladder cancer.

Conclusion: Female gender and stone existence are important factors in the development of metaplasia. Advanced age, gallbladder stone existence and gallbladder wall thickening in ultrasonography are the most important factors in the development cancer. Cholecystectomy should be kept in mind as the most effective method to prevent cancer development in patients have advanced age with gallbladder stones.

Keywords: Gallbladder carcinoma, gallstone, malignancy
Öz

Amaç: Safra kesesi kanseri, gastrointestinal sistemin en yaygın altıncı kanseridir. Klinik prezentasyon safra kesesi taşı veya kolesistitden ayırt edilemez ve çoğu hasta intraoperatif veya postoperatif histolojik incelemede tanı alır. Bu çalışmada, insidental olarak tespit edilmiş safra kesesi kanserli olguların safra kesesi premalign lezyonları, yaş, cinsiyet, ultrasonografi özellikleri ve safra kesesi taşı ile ilişkisi araştııldı.

Yöntemler: Ocak 2012-Aralık 2015 tarihleri arasında kolesistektomi uygulanan 5206 hastanın demografik ve klinik özellikleri, patoloji sonuçları retrospektif olarak değerlendirildi.

Bulgular: Hastaların 3884'ü $(\% 74,6)$ kadındı. Patoloji raporlarında 102 (\%1.95) olguda premalign ve malign lezyonlar olduğu tespit edildi. Metaplazi kadınlarda anlamlı olarak daha fazla iken, displazi ve kanser gelişimi arasında cinsiyete göre anlamlı bir fark bulunamadı. Safra kesesi taşı metaplazi gelişiminde bir risk faktörü olarak bulundu. Safra kesesi duvar kalınlaşmasınınve ileri yaşın safra kesesi kanseri gelişimi için en önemli risk faktörleri olduğu tespit edildi.

Sonuç: Metaplazi gelişiminde kadın cinsiyet ve taş varlığı önemli faktörlerdir. Ultrasonografide safra kesesi duvar kalınlaşması, ileri yaş, safra kesesinde taşı varlığı kanser gelişiminde en önemli faktörlerdir. Kolesistektomi, ileri yaşta safra kesesi taşı olan hastalarda kanser gelişimini önlemek için en etkili yöntem olarak akılda tutulmalıdır.

Anahtar Sözcükler: Safra kesesi kanseri, safra kesesi taşı, malignite
Address for Correspondence/Yazışma Adresi: Murat Ferhat Ferhatoğlu Okan University Faculty of Medicine, Department of General Surgery, İstanbul, Turkey Phone: +90 5553214793 E-mail: ferhatferhatoglu@yahoo.co.uk

Received/Geliş Tarihi: 18 June 2018 Accepted/Kabul Tarihi: 04 September 2018
${ }^{\circ}$ Copyright 2018 by The Medical Bulletin of University of Health Sciences Haseki Training and Research Hospital
The Medical Bulletin of Haseki published by Galenos Yayinevi.

${ }^{8}$ Telif Hakkı 2018 Sağlık Bilimleri Üniversitesi Haseki Eğitim ve Araştırma Hastanes Haseki Tıp Bülteni, Galenos Yayınevi tarafından basılmııstır. 


\section{Introduction}

Gallbladder cancer (GBC) is the sixth most common cancer of the gastrointestinal system, with a worldwide annual incidence of 2.2 per 100,000 and 5-year mortality rate of $90 \%-95 \%(1,2)$.

"Adenomatous polyps, porcelain gallbladder, high body mass index and obesity, chronic inflammation due to Salmonella and Helicobacter infections, smoking, pancreaticobiliary junction anatomy abnormality, primary sclerosing cholangitis, female sex, gallbladder stones, ethnicity, ulcerative colitis, adenomyomatosis, and age > 65 are known risk factors for the development of GBC $(3,4)$

Clinical presentation may not be differentiated from cholelithiasis or cholecystitis, and most patients are diagnosed at the time of surgery or during postoperative histologic examination.

Accepted treatment strategy for Tis (in situ carcinoma) and T1a (tumor invasion to lamina propia) GBC is simple cholecystectomy (5). Cholecystectomy with regional lymph node dissection and wedge resection of the gallbladder bed with $3 \mathrm{~cm}$ margins is recommended for more advanced tumors because of the possibility of micrometastases (6).

The present study aimed to investigate the association of incidentally detected $\mathrm{GBC}$ with premalignant lesions of the gallbladder.

\section{Methods}

In this retrospective study, 5206 patients who underwent cholecystectomy at Bursa State Hospital and Okan Universty, Department of General Surgery, in 20122015 were evaluated. Patients were analyzed according to demographic data and pathological reports. Age, sex, malignant lesions, premalignant lesions, stone presence and ultrasonography reports were evaluated. The study protocol was approved by the Ethics Committee of Okan University, Istanbul (No 94, Date: 09 May 2018).

\section{Statistical Analysis}

SPSS for Windows 23.0 (SPSS Inc., Chicago, IL, USA) was used for the study analysis. Mean and standard deviation of numerical data were used in the study, and frequency and ratio were used in the presentation of categorical data. Chi-square test was used for categorical data, and ROC curve analysis was used to determine the predictive value of age and sex in the development of GBC. $p<0.05$ was considered statistically significant.

\section{Results}

Of 5206 patients, 3884 (74.6\%) were female and 1322 (25.4\%) were male (male/female ratio: 0.34 ); mean age was $52.81 \pm 14.15$ years. Pathological reports showed premalignant and malignant lesions (metaplasia, dysplasia, or carcinoma) in 102 (1.95\%) patients. Prevalence and mean age for premalignant and malignant lesions are shown in Table 1.

ROC curve analysis for age of the patients showed that the predictive value of advancing age was the highest for the development of GBC (AUC $=0.760, p<$ 0.001) (Table 2).

Metaplasia was significantly more common in females (Male/female ratio $=0.29, p=0.022)$, whereas no significant difference was found between sex and the development of dysplasia (Male/female ratio $=0.83$, $p=0.167)$ and between sex and the development of carcinoma (Male/female ratio $=0.7, p=0.173$ ).

\begin{tabular}{|l|l|l|}
\hline \multicolumn{2}{|l|}{$\begin{array}{l}\text { Table 1. Prevalence and mean age for premalignant and } \\
\text { malignant lesions of the gallbladder }\end{array}$} \\
\hline Lesion & $\mathbf{n = 1 0 2}(\%)$ & Age (mean \pm SD) years \\
\hline Metaplasia & $74(64 \%)$ & $54.18 \pm 13.5$ \\
\hline Dysplasia & $11(9 \%)$ & $54.63 \pm 14.2$ \\
\hline Carcinoma & $17(15 \%)$ & $70.79 \pm 10.1$ \\
\hline
\end{tabular}

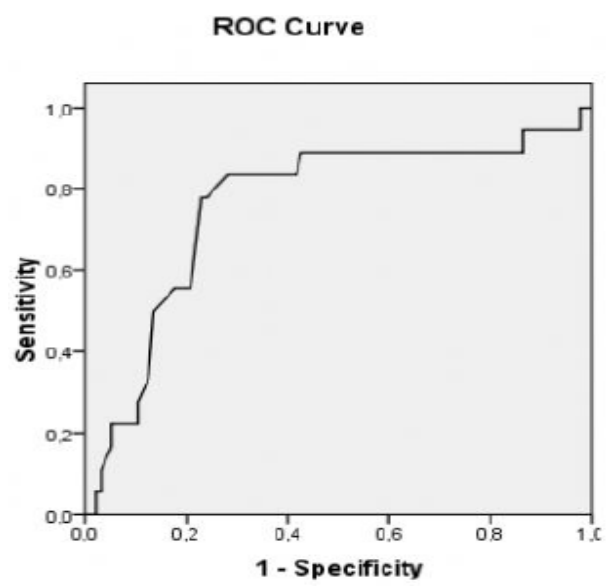

Area under the curve

Table 2. Age and GBC predictive value

\begin{tabular}{|l|l|l|l|l|}
\hline \multirow{2}{*}{ Area } & \multirow{2}{*}{$\begin{array}{l}\text { Standard } \\
\text { error }\end{array}$} & $\begin{array}{l}\text { Asymptomatic } \\
\text { Sig }\end{array}$ & \multicolumn{2}{|l|}{$\begin{array}{l}\text { Confidence } \\
\text { Interval }\end{array}$} \\
\cline { 4 - 5 } & & $\begin{array}{l}\text { Lower } \\
\text { bound }\end{array}$ & $\begin{array}{l}\text { Upper } \\
\text { bound }\end{array}$ \\
\hline 0.760 & 0.067 & 0.000 & 0.630 & 0.891 \\
\hline \multicolumn{4}{|l|}{ Predictive value of age for the development of GBC } \\
\hline
\end{tabular}


Presence of gallbladder stones was a risk factor for the development of metaplasia and carcinoma; however, it did not have an effect on the development of dysplasia (Table 3).

Ultrasonography (US) results of 95 patients were evaluated (data of seven patients were missing) according to the thickening of the gallbladder wall and size and number of gallbladder stones. Increased thickening of the gallbladder wall was significantly more common in GBC according to metaplasia and carcinoma (Table 5).

Of 17 carcinomas, $13(76.4 \%)$ were in the corpus of the gallbladder and five had cystic duct invasion. Five were at the in-situ stage (Table 4). All patients with cystic duct invasion had perineural and vascular infiltration. Overall survival of the patients with cystic duct invasion was 15.2 \pm 8.98 years.

\section{Discussion}

GBC is the twentieth most common cancer, and it is the most common cancer of the biliary tract, with 178,801 new cases and 142,823 deaths recorded in 2012 (2). Approximately $65 \%$ of GBC cases occur in less developed countries. Chile has the highest rate of GBC incidence,

\begin{tabular}{|l|l|l|l|}
\hline $\begin{array}{l}\text { Table 3. Risk factors associated with gallbladder stones in } \\
\text { pathological results }\end{array}$ & \multicolumn{2}{|l|}{$\begin{array}{l}\text { p } \\
\text { value }\end{array}$} \\
\cline { 1 - 3 } \multirow{2}{*}{ Variables } & No & Yes & \\
\cline { 2 - 3 } & 35 & 39 & \multirow{2}{*}{0.019} \\
\hline Metaplasia & 12 & 16 & \multirow{2}{*}{0.278} \\
\hline Dysplasia Carcinoma & 12 & 0 & \multirow{2}{*}{0.001} \\
\hline Dysplasia & 35 & 56 & \\
\hline Metaplasia Carcinoma & 1 & 16 & 39 \\
\hline Carcinoma & 47 & \multicolumn{2}{|l}{} \\
\hline Dysplasia Metaplasia & &
\end{tabular}

\begin{tabular}{|c|c|c|c|c|c|}
\hline \multicolumn{2}{|c|}{ US results } & \multirow{2}{*}{$\begin{array}{l}\text { Metaplasia } \\
20\end{array}$} & \multirow{2}{*}{$\begin{array}{l}\text { Dysplasia } \\
1\end{array}$} & \multirow{2}{*}{$\begin{array}{l}\text { Carcinoma } \\
6\end{array}$} & \multirow{2}{*}{$\begin{array}{l}p \\
\text { Value }\end{array}$} \\
\hline$\underline{n}$ & Yes & & & & \\
\hline $\begin{array}{l}\frac{5}{0} \\
\frac{\bar{v}}{\Sigma}\end{array}$ & No & 49 & 8 & 11 & $\stackrel{m}{o}$ \\
\hline \multirow{2}{*}{ 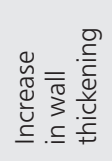 } & Yes & 6 & 1 & 12 & \multirow{2}{*}{ চे } \\
\hline & No & 63 & 8 & 5 & \\
\hline \multirow{2}{*}{ 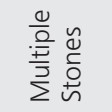 } & Yes & 41 & 1 & 12 & \multirow{2}{*}{ 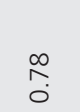 } \\
\hline & No & 28 & 8 & 5 & \\
\hline
\end{tabular}

Table 5. T stage, size, localization, histological subtype, cystic duct invasion and survival time of 17 GBC patients

\begin{tabular}{|c|c|c|c|c|c|c|c|}
\hline $\begin{array}{l}\text { ळ } \\
\text { లే }\end{array}$ & ॐ & $\begin{array}{l}\text { 巴ँ } \\
\text { के } \\
1\end{array}$ & $\begin{array}{l}\widehat{E} \\
\frac{E}{\tilde{N}} \\
\text { क }\end{array}$ & 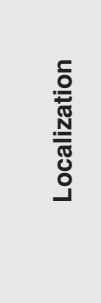 & 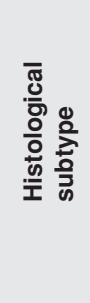 & 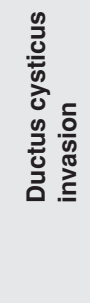 & 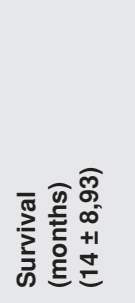 \\
\hline 1 & M & Tis & 30 & Corpus & $A C$ & No & Unknown" \\
\hline 2 & $F$ & T3 & 40 & Fundus & AsC & No & 6 \\
\hline 3 & $\mathrm{~F}$ & T4 & 17 & Corpus & $A C$ & Yes & 2 \\
\hline 4 & $\mathrm{~F}$ & Tis & 4 & Corpus & $A C$ & No & Alive \\
\hline 5 & $\mathrm{~F}$ & T4 & 24 & Corpus & $A C$ & Yes & 22 \\
\hline 6 & $\mathrm{M}$ & T4 & 31 & Corpus & $A C$ & Yes & 10 \\
\hline 7 & $\mathrm{~F}$ & Tis & * & Corpus & $A C$ & No & Deceased $†$ \\
\hline 8 & $\mathrm{~F}$ & Tis & * & Corpus & $A C$ & No & Alive \\
\hline 9 & M & Tis & * & Corpus & $A C$ & No & Alive \\
\hline 10 & M & Tis & * & Corpus & $A C$ & No & Alive \\
\hline 11 & $\mathrm{~F}$ & Tis & * & Corpus & $A C$ & No & Alive \\
\hline 12 & M & T4 & 25 & Corpus & $A C$ & Yes & 19 \\
\hline 13 & $\mathrm{M}$ & T4 & 25 & Fundus & $A C$ & No & 26 \\
\hline 14 & $\mathrm{~F}$ & T1 & 3 & Fundus & $A C$ & No & Unknown" \\
\hline 15 & $\mathrm{~F}$ & T4 & 30 & Corpus & $A C$ & Yes & 23 \\
\hline 16 & $\mathrm{M}$ & T4 & 21 & Corpus & $A C$ & No & 4 \\
\hline 17 & $\mathrm{~F}$ & T1 & 2 & Fundus & $A C$ & No & Alive \\
\hline
\end{tabular}

Table 6. Studies assessing GBC incidence

\begin{tabular}{|l|l|l|l|l|}
\hline Studies & Duration & Place & $\begin{array}{l}\text { Sample } \\
\text { size }\end{array}$ & $\begin{array}{l}\text { GBC } \\
\text { Incidence } \\
(\%)\end{array}$ \\
\hline $\begin{array}{l}\text { Zhang WJ et al. } \\
\text { (2009) (23) }\end{array}$ & $\begin{array}{l}1999- \\
2007\end{array}$ & China & 10466 & 0.19 \\
\hline $\begin{array}{l}\text { Glauser et al. } \\
\text { (2010) (24) }\end{array}$ & $\begin{array}{l}1994- \\
2004\end{array}$ & Switzerland & 30960 & 0.28 \\
\hline $\begin{array}{l}\text { Antonakis et al. } \\
\text { (2003) (25) }\end{array}$ & $\begin{array}{l}1990- \\
2000\end{array}$ & Greece & 5539 & 0.19 \\
\hline $\begin{array}{l}\text { Yi et al. (2013) } \\
(26)\end{array}$ & $\begin{array}{l}1992- \\
2009\end{array}$ & China & 14037 & 0.17 \\
\hline $\begin{array}{l}\text { Koshenkov et } \\
\text { al. (2013) (27) }\end{array}$ & $\begin{array}{l}1996- \\
2011\end{array}$ & USA & 26572 & 0.25 \\
\hline $\begin{array}{l}\text { Genc V et al. } \\
\text { (2011) (28) }\end{array}$ & $\begin{array}{l}1999- \\
2010\end{array}$ & Turkey & 5164 & 0.09 \\
\hline Present study & $\begin{array}{l}2012- \\
2015\end{array}$ & Turkey & 5206 & 0.32 \\
\hline
\end{tabular}


followed by Bolivia. Izarzugaza et al. reported the GBC incidence in females and males as $17.1 \%$ and $7.3 \%$, respectively. Geographical variations may affect the GBC incidence. The disease is more frequent in Central and South America which may be related to widespread Salmonella infection and aflatoxin B contamination in dried Capsicum Annuum L. (or red chili peppers). Zhang et al. reported GBC incidence of $0.19 \%$ in China (Table 6) $(7,8)$. Different incidence rates may be attributed to variations in ethnicity, geography, socioeconomic background, race and eating habits. In addition, inadequate preoperative examination in less developed countries may be the reason this variation.

GBC is detected incidentally in $0.1 \%-0.3 \%$ of all cholecystectomies. In the present study, incidental GBC incidence is $0.32 \%$. Selective histopathological examination is recommended by some authors $(9,10)$. However, Jha et al. advocated the importance of standard histopathological examination. They found that 9 of 20 GBC cases showed no evidence of GBC in macroscopic examination (11). In addition, standard histopathological examination of specimens is recommended by the Royal College of Pathologists (12). A significant pathology may be found with normal gross examination; however, most GBC specimens demonstrate the same morphologic features with thickened and fibrotic walls, mucosal ulceration and nodular mucosa.

Only $30 \%$ of patients are suspected of having GBC before gallbladder surgery, and $15 \%-25 \%$ of them are eligible for surgical treatment (1). Expert consensus and the National Comprehensive Cancer Network guidelines recommend simple cholecystectomy for Tis and $\mathrm{T} 1 \mathrm{a}$ GBC. For T1b or higher tumors, guidelines recommend cholecystectomy with radical liver resection, portal lymphadenectomy and resection of common bile duct, if necessary, to obtain R0 resection (13). Over the past decades, surgical mortality has decreased, and extended resection of the gallbladder and liver segment 4b-5 has resulted in improved survival. Surprisingly, Kamusova et al. revealed that simple cholecystectomy with adjuvant therapy has an advantage over extended surgical resection of the gallbladder and liver bed. Although further studies are needed on this subject (1), the rarity of this disease prevents prospective studies

In the present study, premalignant and malignant lesions of the gallbladder are more frequently observed in females, but female sex is a significant risk factor only for the development of metaplasia and not for the development of GBC. Although GBC was more frequently observed in females, female sex was not identified as a significant risk factor in our study, which is different from the data in the literature $(7,14,15)$. The limited number of
GBC cases in our study may be the cause of this difference. Female sex hormones may be linked to the development of premalignant and malignant lesions of the gallbladder. Estrogen increases the secretion of xenobiotics and cholesterol. Progesterone also impairs contractility of the gallbladder and prolongs gallbladder residence time of bile. However, further studies are needed on this subject (16).

Advanced age is another known risk factor for the development of $G B C$, because patients with $G B C$ tend to be older (17). Consistent with data in the literature, our study found that advanced age is a significant risk factor and the most important risk factor for the development of GBC (Table 2). Ahn et al. found that age of 65 years or more is the only independent predictor for GBC (18). In the study by Hundal and Shaffer, metaplasia, dysplasia and carcinoma transformation in GBC is thought to have developed over a span of 5-15 years (19). Consistent with the findings of Hundal and Shaffer, we found that mean age of GBC diagnosis $(70.79 \pm 10.1)$ is almost 15 years more than the age of diagnosis for metaplasia and dysplasia (54.18 \pm 13.5 and $54.63 \pm 14.2$ ) (Table 1). Neoplastic cascade of metaplasia-dysplasia-carcinoma requires many years to develop, and this may be the why $\mathrm{GBC}$ incidence is higher in elderly patients.

Gallstones are a well-known potential risk factor for GBC, with an $8.3 \%$ higher risk in patients with gallstones than in the general population (20). GBC develops in only $0.2 \%-3 \%$ of all patients with cholelithiasis (4), but gallbladder stones are present in $90 \%$ of patients with GBC (21). Waghmare et al. reported that gallstones have a high association with GBC (22). Jha et al. also reported that 14 of $20 \mathrm{GBC}$ cases were associated with gallstones (11). A cohort study by Ryu et al. also showed that gallstones were associated with increased risk of mortality in GBC (23). Shaffer argued that patients with gallstones larger than $3 \mathrm{~cm}$ had a $4 \%$ risk of developing GBC over 20 years (24). Hamdani et al. reported that in 198 GBC cases diagnosed in Jan 2004-Dec 2011, 86\% of patients presented with gallstone (25). They supported this association by reporting that the routine scenario for $\mathrm{GBC}$ was elderly women with gallstones. De Aretxabla et al. reported that 53 of 54 patients with resectable GBC presented with gallstones (26). Gallstones and chronic inflammation caused by gallstones have the potential to create metaplasia, and it was demonstrated that metaplasia in gallbladder can cause the development of dysplastic epithelium, which plays a role in the development of GBC (27). Wistuba and Gazdar showed that the multi-step pathogenesis sequence of gallstone to carcinoma may take over 20 years (28). A review article by Shrikhande et al. supports prophylactic cholecystectomy in patients with 
cholelithiasis in populations having a higher GBC incidence (29). However, some authors argue against gallstones as a potential cause of

GBC. Maringhini et al. followed 2583 patients with gallstones, and GBC occurred in only five patients $(0.19 \%)$. Thus, an overall cumulative GBC incidence was found to be $1 \%$ for 20 years after the initial diagnosis of gallstone in patients who do not undergo cholecystectomy (30). An old but valuable study of Comfort et al. reported only $1 \%$ of silent gallstone patients developed GBC (31). Acalculous GBC cases are another source of debate. Gallbladder polyps, parasites or cholestasis are thought to be the reason for acalculous GBC. Literature data is far from establishing a causative role for cholelithiasis in the development of GBC. Most authors support the relationship between gallstones and $G B C$, but low $G B C$ incidence in patients with cholelithiasis raises suspicion about this hypothesis. In our study, the presence of gallstones was found to be a risk factor for the development of metaplasia and carcinoma (Table 3).

Gallbladder wall thickening is a sign of inflammation that can be determined in ultrasonography. In ultrasonography, gallbladder carcinoma may also present with generalized mural thickening replacing gallbladder lumen. In our study, gallbladder thickening in ultrasonography is more frequent in carcinoma cases than in metaplasia and dysplasia cases (Table 4). Increasing gallbladder wall thickening may be a warning sign for GBC in patients with epidemiological and genetic risk factors.

Adenocarcinoma is the most frequent subtype of gallbladder carcinomas with an incidence of $95 \%$. It is mostly located in the fundus (60\%), corpus (30\%) and neck (10\%) of the gallbladder (24). Epidermoid carcinoma and adenosquamous carcinoma are other rare subtypes. The most common histological subtype of adenocarcinoma is unspecified type (87.7\%), followed by papillary (6.9\%) and mucinous adenocarcinomas (3.8\%) (25). Of 17 cases reported by us, 16 are unspecified subtype adenocarcinomas (94.2\%) and one is adenosquamous carcinoma (5.8\%). In contrast with the literature, the most common localization of carcinoma in our case series is the corpus of the gallbladder (Table 5). Hamdani et al. reported that the corpus was the most common localization, which is consistent with our findings. Shindoh et al. categorized localization by peritoneal-surface localized and hepaticsurface localized. They revealed that peritoneal-surface carcinomas had better prognosis. The reason for different localization of GBC may be the limited number of GBC cases in this study (32).

In the study by Nakata et al., cystic duct invasion was associated with poor prognosis because of high incidence of concomitant perineural invasion and lymph node metastasis. In accordance with the study by Nakata et al., in our study, five of seven T4 stage cases had cystic duct invasion and all had perineural and vascular infiltration. Overall survival of these patients was $15.2 \pm 8.98$ years (Table 5) (33). Patients without cystic duct invasion had better survive rates (six patients survived). However, the difference in survival between patients with cystic duct invasion and without cystic duct invasion is not significant. The limited number of GBC cases in our study may be a reason for this result.

\section{Conclusion}

$\mathrm{GBC}$ is one of the deadliest cancers, with a short life expectancy from the time of diagnosis. It is difficult to make a preoperative diagnosis of this cancer, and the definitive treatment is surgery. The diagnosis of GBC should be considered, particularly in individuals in the high-risk group/population, with genetic predisposition and with an increase in gallbladder wall thickening in ultrasonography and in elderly patients with gallstones. Cholecystectomy should be considered as the most effective method to prevent the development cancer in patients of advancing age and females with gallbladder stones. The limitations of the present study include its retrospective nature and limited number of patients. Further scientific studies are needed to identify risk factors, improve early diagnosis and minimize the mortality rate of GBC.

\section{References}

1. Kasumova GG, Tabatabaie O, Najarian NM, et al. Surgical Management of Gallbladder Cancer: Simple Versus Extended Cholecystectomy and the Role of Adjuvant Therapy. Ann Surg. 2017; 4: 625-31.

2. Ferlay J, Soerjomataram I, Evrik M et al. GLOBOCAN 2012 v.10, Cancer incidence and mortality Worldwide: IARC Cancer Base No:11 Lyon, France

3. Sharma A, Sharma KL, Gupta A, et al (2017) Gallbladder cancer epidemiology, pathogenesis and molecular genetics: Recent update. World J Gastroenterol. 14: 3978-98

4. Goetze TO. Gallbladder carcinoma: Prognostic factors and therapeutic options. World J Gastroenter. 2015; 21: 1221117.

5. Lee SE, Jang JY, Lim CS, Kang MJ, Kim SW. (2011) Systematic review on surgical treatment fot T1gallbladder cancer. World J Gastroenterol. 17: 174-80.

6. Eckel F, Brunner T, Jelic S; ESMO Guidelines Working Group. Biliary cancer: ESMO Clinical Practice Guidelines for diagnosis, treatment and follow-up. Ann Oncol. 21: 65-9.

7. Izarzugaza I, Fernandez L, Forman D, Sierra MS. Burden of gallbladder cancer in Central and South America. Cancer Epidemiol. 2016; 44: 82-9.

8. Zhang WJ, Xu GF, Zou XP, et al (2009) Incidental Gallbladder Carcinoma Diagnosed During or After Laparoscopic Cholecystectomy. World J Surg 33: 2651-6. 
9. Talreja V, Ali A, Khawaja R, Rani K, Samnani SS, Farid FN. Surgically resected gall bladder: Is histopathology needed for all? Surg Res Pract 2016. 20169319147.

10. Dix FP, Bruce IA, Krypcyzk A, Ravi S. A selective approach to histopathology of the gallbladder is justifiable. Surgeon. 2003;1:233-5.

11. Jha $V$, Sharma $P$, Mandal KA. Incidental gallbladder carcinoma: Utility of histopathological evaluation of routine cholecystectomy specimens. South Asian J Cancer. 2018; 7: 21-3.

12. Royal college of pathologist. Histopathology of limited or no clinical value. Report of Working Group of Royal College of Pathologist 2nd ed. London, 2002

13. National Compheresive Cancer Network. NCCN Clinical Practice Guideklines in Oncology: Hepatobiliary cancers. Version 2.2016. Available t: www.nccn.org

14. Pitt SC, Jin LX, Hall BL, Strasberg SM, Pitt HA. Incidental gallbladder cancer at cholecystectomy: when should the surgeon be suspicious? Ann Surg. 2014; 260:128-33.

15. Kayahara M, Nagakawa T, Nakagawara H, Kitagawa $H$, Ohta T. Prognostic factors for gallbladder cancer in Japan. Ann Surg. 2008; 248: 807-14.

16. Pilgrim CH, Groeschl RT, Christians KK, et al. Modern perspectives on factors predisposing to the development of gallbladder cancer. HPB(Oxford). 2013; 15: 839-44.

17. Gupta S, Kori C, Kumar V, et al. Epidemiological study of gallbladder cancer. Patients from North Indian Gangetic Planes- A high volume centre's experience. J Gastrointest Canc. 2016; 47: 27-35.

18. Ahn Y, Park CS, Hwang S, Jang HJ, Choi KM, Lee SG. Incidental gallbladder cancer after routine cholecystectomy: when should we suspect it preoperatively and what are predictors of patient survival? Ann Surg Treat Res 2016; 90: 131-138

19. R. Hundal and E.A. Shaffer (2014) Gallbladder cancer: epidemiology and outcome. Clinical Epidemiol. 6: 99-109.

20. Kanthan K, Senger JL, Ahmed S, et al. Gallbladder cancer in the 21st centruy. J Oncol. 2015: 967472.

21. Ghimire P, Yogi N, Shrestha BB. Incidence of incidental carcinoma gallbladder in cases of routine cholecystectomy. Kathmandu University Med Journal. 2011; 34: 3-6.
22. Waghmare RS, Kamat RN. Incidental Gall Bladder Carcinoma in Patients Undergoing Cholecystectomy: A Report of 7 Cases. J Assoc Physicians India. 2014;62: 793-6.

23. Ryu S, Chang Y, Yun KE, Jung HS, Shin JH, Shin H. Gallstones and the Risk of Gallbladder Cancer Mortality: A Cohort Study. Am J Gastroenterol. 2016; 111:1476-87.

24. Shaffer EA. Gallbladder Cancer The Basics. Gastroenterol Hepatol. 2008; 4: 737-41.

25. Hamdani NH, Qadri SK, Aggarwalla R, et al. Clinicopathological Study of Gall Bladder Carcinoma with Special Reference to Gallstones: Our 8-year Experience from Eastern India. Asian Pac J Cancer Prev. 2012; 13: 5613-7.

26. X. De Aretxabala, I. Roa, L Burgos, et al. Gallbladder cancer in Chile: A report on 54 potentially resectable tumors. Cancer. 1992; 69: 60-5.

27. Seretis C, Lagoudianakis E, Gemenetzis G, et al (2014) Metaplastic Changes in Chronic Cholecystitis: Implications for Early Diagnosis and Surgical Intervention to Prevent the Gallbladder Metaplasia-Dysplasia-Carcinoma Sequence. J Clin Med Res. 6: 26-9.

28. Wistuba II, Gazdar AF (2004) Gallbladder cancer: Lessons from a rare tumour. Nat Rev Cancer. 4: 695-706.

29. Shrikhande SV, Barreto SG, Singh S, et al (2010) Cholelithiasis in gallbladder cancer: Coincidence, cofactor, or cause! Eur J Surg Oncol. 36: 514-19.

30. Maringhini A, Moreau JA, Melton LJ 3rd, Hench VS, Zinsmeister AR, DiMagno EP. Gallstones, gallbladder cancer, and other gastrointestinal malignancies. An epidemiologic study in Rochester, Minnesota. Ann Intern Med. 1987; 107: 30-5

31. Comfort MW, Gray HK, Wilson JM . The silent gallstones: a 10-20 year follows up. Ann Surg. 1948; 128: 931-6.

32. Shindoh J, de Aretxabala X, Aloia TA et al. Tumor location is a strong predictor of tumor progression and survival in T2 gallbladder cancer: an international multicenter study. Ann Surg. 2015; 261: 733-9

33. Nakata T, Kobayashi A, Miwa S, et al (2007) Impact of Tumor Spread to the Cystic Duct on the Prognosis of Patients with Gallbladder Carcinoma. World J Surg. 31: 155-61. 